\title{
Educational technology for fatigue management related to antineoplastic chemotherapy
}

\author{
Tecnologia educativa para manejo da fadiga relacionada à quimioterapia antineoplásica \\ Tecnología educativa en el manejo de la fatiga relacionada con la quimioterapia antineoplásica
}

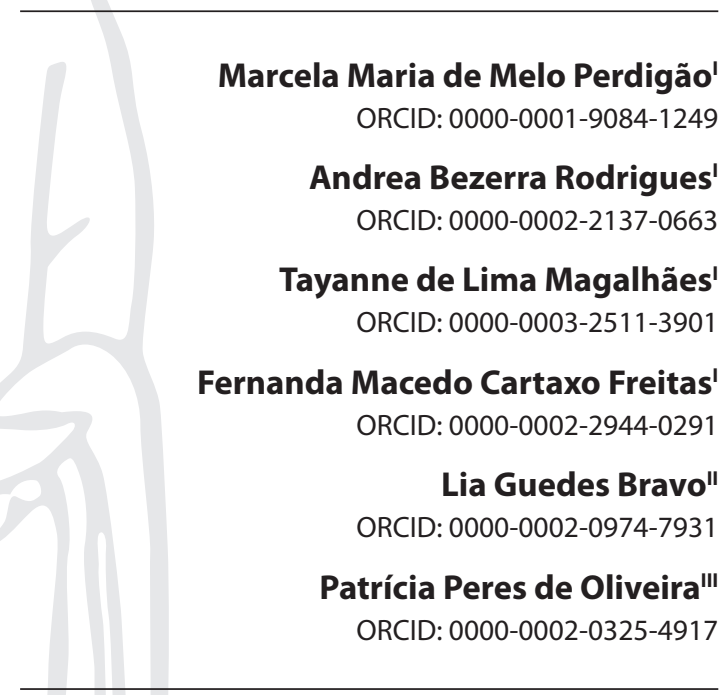

'Universidade Federal do Ceará. Fortaleza, Ceará, Brazil. "Universidade Estadual do Ceará. Fortaleza, Ceará, Brazil.

"'Universidade Federal de São João Del Rei. Divinópolis, Minas Gerais, Brazil.

How to cite this article:

Perdigão MMM, Rodrigues AB, Magalhães TL, Freitas FMC, Bravo LG, Oliveira PP. Educational technology for fatigue management related to antineoplastic chemotherapy. Rev Bras Enferm. 2019;72(6):1519-25. doi: http://dx.doi.org/10.1590/0034-7167-2018-0505

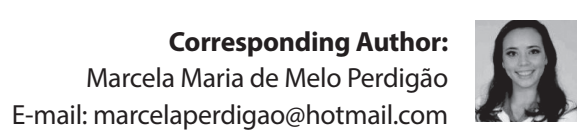

Submission: 06-14-2018 Approval: 04-10-2019

\begin{abstract}
Objective: To construct and validate an educational technology (ET) on fatigue and nonpharmacological strategies for the management of this symptom in people with cancer undergoing outpatient antineoplastic chemotherapy. Method: This is a methodological study composed of three stages: 1) elaboration of the ET using the theoretical-methodological model of Doak, Doak and Root; 2) validation of content and appearance by seven nurses via the content validity index (CVI); and 3) a pilot test with 10 patients. Results: The ET "Knowing and coping with fatigue" contemplates the definition of fatigue, its causes and the interventions of physical exercise practice, sleep hygiene, energy conservation and behavioral intervention. The overall CVI obtained with the judges was 0.95 . Conclusion: The ET presented content and appearance validity for health education regarding fatigue related to antineoplastic chemotherapy in outpatient cancer patients.

Descriptors: Patient Care Bundles; Oncology Nursing; Fatigue; Validation Studies; Educational Technology.
\end{abstract}

\section{RESUMO}

Objetivo: Construir e validar tecnologia educativa (TE) sobre fadiga e estratégias não farmacológicas para manejo desse sintoma em pessoas com câncer em tratamento quimioterápico antineoplásico ambulatorial. Método: Estudo metodológico composto por três etapas: 1) elaboração da TE, utilizando o modelo teórico-metodológico de Doak, Doak e Root; 2) validação de conteúdo e aparência por sete juízes enfermeiros, por meio do índice de validade de conteúdo (IVC); e 3) realização de teste piloto com 10 pacientes. Resultados: A TE "Conhecendo e lidando com a fadiga" contempla a definição de fadiga, suas causas e as intervenções de prática de exercícios físicos, higiene do sono, conservação de energia e intervenção comportamental. O IVC global obtido com os juízes foi de 0,95. Conclusão: A TE apresentou validade de conteúdo e aparência para a educação em saúde com relação à fadiga relacionada à quimioterapia antineoplásica em pacientes oncológicos ambulatoriais. Descritores: Pacotes de Assistência ao Paciente; Enfermagem Oncológica; Fadiga; Estudos de Validação; Tecnologia Educacional.

\section{RESUMEN}

Objetivo: Construir y validar una tecnología educativa (TE) sobre fatiga y estrategias no farmacológicas para el manejo del síntoma en personas con cáncer en tratamiento quimioterápico antineoplásico ambulatorio. Método: Estudio metodológico que consta de tres etapas: 1) elaboración de la TE utilizando el modelo teórico-metodológico de Doak, Doak y Root; 2) validación de contenido y apariencia por siete jueces enfermeros, por medio del índice de validez de contenido (IVC); y 3 ) realización de una prueba piloto con 10 pacientes. Resultados: La TE "Conociendo y lidiando con la fatiga" contempla la definición de fatiga, sus causas y las intervenciones con la práctica de ejercicios físicos, la higiene del sueño, la conservación de energía y la intervención comportamental. El IVC total obtenido con los jueces fue de 0,95. Conclusión: La TE presentó validez de contenido y apariencia para la educación en salud con relación a la fatiga relacionada a la quimioterapia antineoplásica en pacientes oncológicos ambulatorios.

Descriptores: Paquetes de Atención al Paciente; Enfermería Oncológica; Fatiga; Estudios de Validación; Tecnología Educacional. 


\section{INTRODUCTION}

In oncology, an ever increasing number of pharmacological and non-pharmacological strategies have been implemented to care for patients with cancer. In spite of this, both the disease and its therapy trigger many signs and symptoms - among them, fatigue.

Cancer-related fatigue is defined as "a subjective and persistent sensation of tiredness, physical, emotional and/or cognitive exhaustion, disproportionate to any recent activity, and that does not improve with rest and sleep, interfering in the activities of daily living"(1). Fatigue is also described in the Nursing Diagnostic Classification proposed by NANDA-I, described as"an overwhelming sustained sense of exhaustion and decreased capacity for physical and mental work at the usual level"(2).

This symptom is often experienced by cancer patients and affects about 75 to $95 \%$ of them, leading to compromises of daily living activities ${ }^{(3)}$. In a study that compared adults with cancer to another group of adults without the disease, $56 \%$ of the cancer population experienced fatigue ${ }^{(4)}$.

Due to being a health problem, one of the obstacles related to its detection is that patients associate fatigue with the ineffectiveness of therapy - believing that it is necessary to stop it - or, believing that fatigue indicates the evolution of the disease. Thus, providing clarification about this symptom and its natural history to patients is fundamental due to causing such effect, especially patients who will undergo antineoplastic chemotherapy ${ }^{(5)}$.

Therefore, educational programs conducted by health professionals, including the use of technologies, are fundamental for the patient to adapt to and cope with fatigue. Counseling should be started from the first meeting, involving orientation on exercise practice, balancing activities and day-to-day rest, establishing priorities and delegating tasks, relaxation techniques, sleep hygiene measures, feeding and dietary supplementation ${ }^{(6)}$.

Given this context, the role of nurses stands out since nonpharmacological interventions can reduce patient fatigue, something that has already been proven in a study about its benefit ${ }^{(7)}$. Educational Technologies (ET) have contributed significantly to support the guidance provided.

\section{OBJECTIVE}

To construct and validate an educational technology on fatigue and non-pharmacological strategies to cope with this symptom in people with cancer undergoing outpatient antineoplastic chemotherapy.

\section{METHOD}

\section{Ethical aspects}

This study was approved by the Research Ethics Committee of the Walter Cantídio University Hospital/Universidade Federal do Ceará. Participants involved in the study signed an informed consent form. The ethical precepts of research with human beings, based on Resolution 466/2012 of the Brazilian National Health Council, were respected.

\section{Design, study location and period}

This is a three-stage methodological study. The first relates to the construction of the instrument; the second, to the validation of its content and appearance by judges; and the third, the pilot test.

The first stage took place from December 2016 to February 2017 and was guided by the theoretical and methodological framework of Doak, Doak and $\operatorname{Root}^{(8)}$, which presents some essential guidelines for the construction planning of educational materials. They are: a) defining the target audience - although it seems to be an obvious step, it is often neglected; b) limiting and defining the learning objectives, which must be compatible with the desired actions and behaviors from the educational intervention; c) during the construction itself, the active voice must be used in writing, since it makes reading easier and the reader more likely to practice the action; d) writing short sentences and avoiding technical terms that make comprehension difficult; e) including interactions that may make the guidelines simpler to understand and remember; and f) testing to ensure quality ${ }^{(8)}$.

After this stage, content and appearance were evaluated by judges from March to May 2017. The next phase - the pilot study -, occurred in the outpatient chemotherapy clinic of a university hospital in the city of Fortaleza, Ceará, from July to August 2017.

\section{Sample and inclusion and exclusion criteria}

In the selection of judges for validation of content and appearance of the educational material, the criteria proposed by Jasper $^{(9)}$ were followed, which indicate that a judge must have a body of specialized knowledge or skill, experience in the field of practice, highly developed levels of recognition of standards and recognition by others. Following, Pasquali's ${ }^{(10)}$ proposal was also used, in which the number of judges must be at least six. To avoid a tie of opinions, this study chose to adopt an odd number of judges, establishing seven as the number of judges.

Thus, the seven judges were selected according to their clinical and scientific experience with cancer patients on chemotherapeutic treatment through the Lattes platform of the CNPq Portal. The search was conducted using the simple search option for subject/ keyword (oncology, health education, printed educational materials). Sampling was conducted using the snowball method: when one participant was selected according to the established criteria, such participant recommended another with the same characteristics.

During the pilot test stage, the sample of patients was delineated based on the hospital records, being composed of 73 individuals. Considering that the suggested sample for a pilot study to be effective is $10 \%{ }^{(11)}$, seven patients were calculated as an effective number and researchers chose to work with 10 to ensure greater efficacy. Sample selection occurred by convenience at the outpatient chemotherapy clinic on the days of collection, meeting the following inclusion criteria: being 18 years old or older, 15 score on the Glasgow scale and undergoing antineoplastic chemotherapy for gastric or colorectal cancer. This last criterion was based on a study that inferred that patients with gastric cancer presented more fatigue ${ }^{(12)}$. The Glasgow scale was applied to ensure that the patient presented adequate level of temporal, personal and spatial orientation, as stressed in the item "verbal 
response" of the scale, as well as an adequate motor response another scale item - to comply some of the guidelines provided for fatigue control, such as performing physical activities. These items, coupled to eye opening, consistently indicate the highest degree of integration of the central nervous system. Regarding colorectal cancer, there are few studies that investigate the presence of fatigue in patients with this neoplasm ${ }^{(13)}$. Finally, also as an inclusion criterion, the patient should score at least $60 \%$ in the Karnofsky index, which indicates one's capacity to take care of their personal needs, requiring only occasional help. Exclusion criteria were: illiteracy; chronic pain; use of megestrol acetate or antidepressants; and/or concomitant radiotherapy, which could have influence on fatigue ${ }^{(14)}$. Megestrol acetate use was considered an exclusion criterion to ensure homogeneity in the sample, since this drug may be indicated for the pharmacological treatment of fatigue in cancer patients, improving the levels of this symptom and increasing the sensation of well-being ${ }^{(6)}$.

\section{Study protocol}

In the first stage of construction of the instrument, a search was made on the databases Medical Literature Analysis and Retrieval System Online (Medline), Latin American Literature in Health Sciences (Lilacs) and Nursing Database (Bdenf), using the Health Sciences Descriptors (DeCS/MeSH) "fatigue", "cancer" and "chemotherapy", with the Boolean term 'and'. Studies published from 2011 to 2016 and that were available in full were considered for this study. In addition to searching the databases, materials published by Brazilian Consensus on Fatigue (Consenso Brasileiro de Fadiga) $)^{(6)}$, Oncology Nurses Society (ONS), American Society of Clinical Oncology (Asco) and Brazilian Cancer Institute (Instituto Nacional de Câncer - Inca) were also used.

The folder's image design, typography, choice of colors and layout mas made with the help of a visual arts professional. The researchers received updates on the process to provide their feedback and approval. The art was done in the program Adobe Photoshop CC 2015.

After finishing the preparation of the ET, an invitation letter was sent to the judges with a brief presentation of the research project, the objective to be evaluated, an explanation of the importance of its validation for later use in practice and what would be his/her function as a judge. After the accepting, the judges received an informed consent form, the ET and the instrument for content and appearance validation of the technology via e-mail. The content and appearance validation instrument was made using the Google Forms program. The validation questionnaire was adapted from Oliveira, Fernandes and Sawada ${ }^{(15)}$. This instrument is divided into two parts: the first contains the characterization data on the judge, and the second presents the instructions for completion and the items to be evaluated (objectives, structure, presentation, relevance and content). The judges were asked to evaluate the ET regarding its content and appearance, with responses given by a Likert-type scale -1 = inadequate; 2 = partially adequate; 3 = adequate; and $4=$ totally adequate ${ }^{(15)}$-, as well as a space for comments and suggestions when options 1 and 2 were marked. On average, the reviews were returned to researchers after 30 days.

The third step refers to the pilot test performed with the patients from an outpatient chemotherapy clinic. After the validation process with the judges, the instrument was applied by three trained interviewers. They followed a standard operating procedure elaborated by the authors, containing conceptual and operational definitions.

Patients were guided about their participation, having their anonymity and confidentiality of information ensured. All participants signed an informed consent form. Following, they answered a validation questionnaire adapted from Oliveira, Fernandes and Sawada ${ }^{(15)}$, containing instructions for completing the instrument and the items to be evaluated regarding the objectives, organization, writing style, appearance and motivation of the ET.

\section{Analysis of results and statistics}

Data were organized in a spreadsheet in the statistical software Microsoft Excel 2007. After tabulation, data were analyzed by descriptive statistics.

To perform the agreement analysis of the experts, the Content Validity Index (CVI) method was adopted, which measures the proportion or percentage of experts who agree on certain aspects of an instrument and its items. This study adopted $<0.80$ CVI values, i.e., equivalent to $80 \%$ agreement among the judges, which is considered to be great for the items to be considered validated $^{(16)}$. The CVI was calculated by summing the number of responses marked as " 3 " or " 4 " by the judges and dividing the result by the total number of responses. Moreover, the written suggestions made by the judges were considered.

\section{RESULTS}

The elaboration of the first version of the instrument was made based on 34 studies identified in the selected databases, which were organized in the following categories: presence of fatigue in cancer patients; health-related quality of life (HRQoL) in cancer patients undergoing antineoplastic chemotherapy; fatigue management by non-pharmacological methods in cancer patients undergoing antineoplastic therapy; and interpretation of family members of the factors that can cause fatigue. Of these, the categories "the presence of fatigue in cancer patients" and "fatigue management by non-pharmacological methods in cancer patients undergoing antineoplastic chemotherapy" were considered relevant in the preparation of the preliminary version of the instrument. The educational technology named "Knowing and coping with fatigue" (Conhecendo elidando com a fadiga), was composed by three topics in its final version - the last topic has four subtopics.

Initially, the technology explains the definition of fatigue, its causes, and what can be done to improve the condition. The last topic covers non-pharmacological interventions for fatigue management: "Practice physical exercises", "Improve your sleep" and "Conserve your energy" and a subtopic with no specific title with information on behavioral intervention. Each of these subtopics presents an explanation of the concept of each intervention and how to apply each of them. Finally, part of the bibliography used is presented.

After completing the elaboration of the text, the selection of images began by performing an electronic search on Google Images; these images were sent to the visual arts professional so he could understand the idea that the illustrations were supposed to evoke, as they would be placed close to the texts to which they 
referred, to represent some information from the ET. The text was written in Garamond typeface, size 13 for the information, size 14 for the subheadings and size 28 for the title of the cover, and for subheadings and the title bold was also applied. Text boxes were used for pieces of information that required greater emphasis, using letter size 13 or 16 in bold or with a call for "attention". A4-size coated paper with a light-colored background was used with black text and colored printing.

After finishing the ET, the content and appearance validation was performed by seven judges, all of whom were nurses and female. Most judges had a master's degree (57.1\%), followed by Ph.D (28.5\%); the training time of most was over 20 years (85.7\%); and the professional practice time greater than 15 years (85.7\%). Regarding professional practice, most were professors $(57.1 \%)$ and others worked in care $(42.8 \%)$, considering that, of these, $14.2 \%$ work in clinical oncology, $14.2 \%$ in palliative care and pain, and $14.2 \%$ quality in oncology. Regarding scientific publication, most were judges who published articles on cancer, ET, and instrument validation (71.4\%).

The CVI result obtained for the item "objectives" was 0.93; 0.94 for structure and presentation; and 1.0 for relevance. The global IVC score was 0.95 , thus assuring the validity of the content and appearance of the folder for use in the target population (Table 1).

One of the topics in "objectives", represented by the question "Is this folder capable of promoting changes in behavior and attitude?", obtained a $0.71 \mathrm{CVI}$. In the comments, the judges stated that behavioral change is something more complex, requiring a more specific indicator for evaluation, and also that the ET alone would not be able to promote changes without proper individual follow-up.

Another item, represented by the question "Does the folder provide relevant information and guidance that contributes to the health education process?", showed a 0.86 CVI. Two judges classified it as "partially adequate". One of the judges advised that the suggestion for swimming should be removed as an intervention, which was justified by these patients being immunosuppressed. Moreover, they stressed the importance having the medic responsible for the patient allowing them practice physical exercises. Another judge commented that the use of sunscreen should be included in the guidelines for physical exercises that are practiced outdoors. Both suggestions were followed.

Regarding the "structure and presentation", the item "Is the font size adequate?" totaled $0.71 \mathrm{CVI}$ score. The judges suggested an increase in the font size. The judge's suggestion was accepted. Given the small space available, font size was increased from 12 to 13 . In the item: "Are the images adequate?", $0.86 \mathrm{CVI}$, a judge considered it "partially adequate", explaining that the cover should contain the image of an energetic person, conveying a positive message. This suggestion was accepted and the image of the ET cover was modified.

Still considering "structure and presentation", in the item "Is the typeface adequate?", although it presented 1.0 CVI, a judge stated that the typeface used was tiring and suggested that it was changed to the Calibri typeface. However, the style used is in accordance with the guidelines proposed by the theoretical reference adopted: a serif typeface and size starting from 12 . Therefore, the suggestion was not complied to.

There were other specific questions on items with CVI greater than 0.80 , such as changing the word "tumor" to "disease", rephrasing the sentence "Seek to know more about your fatigue" to "Seek to know more about the cause(s) of your fatigue" and to perform the necessary grammar corrections. Therefore, the material was sent to be revised by a specialized professional.

As general comments, the judges stressed the excellent proposal of the ET to address a symptom that is so little known and valued and that nurses have difficulty to approach, arousing the need for greater knowledge of the professional.

The CVI values of all items analyzed by the judges are described in Table 1.

Table 1 - Content validity index of all items (objectives, structure and presentation, relevance and overall index), according to the analysis of the judges, Fortaleza, Ceará, Brazil, 2017

\begin{tabular}{|c|c|}
\hline Items & CVI \\
\hline Objectives & 0,93 \\
\hline $\begin{array}{l}\text { 1) Does the folder cover the needs of cancer patients } \\
\text { undergoing chemotherapy and facing fatigue? }\end{array}$ & 1,00 \\
\hline $\begin{array}{l}\text { 2) Does the folder provide relevant information and } \\
\text { guidance that contributes to the health education process? }\end{array}$ & 0,86 \\
\hline $\begin{array}{l}\text { 3) Is the folder effective for the maintenance of self-care } \\
\text { related to fatigue management? }\end{array}$ & 1,00 \\
\hline $\begin{array}{l}\text { 4) Is the folder capable of promoting changes in behavior } \\
\text { and attitude? }\end{array}$ & 0,71 \\
\hline $\begin{array}{l}\text { 5) Can the folder circulate in the scientific field in the field } \\
\text { of oncology? }\end{array}$ & 1,00 \\
\hline $\begin{array}{l}\text { 6) Can this folder be implemented in the daily clinical practice } \\
\text { of a nurse who works in an outpatient chemotherapy clinic? }\end{array}$ & 1,00 \\
\hline Structure and presentation & 0,94 \\
\hline 1) Is the information presented clearly and objectively? & 1,00 \\
\hline 2) Is the information presented scientifically correct? & 0,86 \\
\hline 3) Does the instrument have a logical sequence? & 1,00 \\
\hline $\begin{array}{l}\text { 4) Is the information well structured in terms of agreement } \\
\text { and spelling? }\end{array}$ & 1,00 \\
\hline 5) Is the typeface adequate? & 1,00 \\
\hline 6) Is the font size adequate? & 0,71 \\
\hline 7) Is the spacing between the lines appropriate? & 1,00 \\
\hline 8) Is the instrument easy to read and to understand? & 1,00 \\
\hline 9) Are the images adequate? & 0,86 \\
\hline $\begin{array}{l}\text { 10) Do the pictures depict what one actually wants to } \\
\text { convey as information? }\end{array}$ & 1,00 \\
\hline Relevance & 1,00 \\
\hline $\begin{array}{l}\text { 1) Is the folder effective in suggesting to the patient he/she } \\
\text { acquires knowledge on managing his/her fatigue at home? }\end{array}$ & 1,00 \\
\hline $\begin{array}{l}\text { 2) Is the instrument relevant for guiding patients with } \\
\text { fatigue who are undergoing chemotherapy? }\end{array}$ & 1,00 \\
\hline $\begin{array}{l}\text { 3) Is the instrument relevant to the care provided by nurses } \\
\text { to these patients? }\end{array}$ & 1,00 \\
\hline $\begin{array}{l}\text { 4) Does this folder allow the transfer of relevant } \\
\text { information about fatigue between the nurse professional } \\
\text { and the patient undergoing chemotherapy? }\end{array}$ & 1,00 \\
\hline Global CVI & 0,95 \\
\hline
\end{tabular}

Note: $C V I=$ Content Validity Index

After applying the changes proposed by the judges and the folder was finished, the pilot test began. Of the 10 participants, six $(60 \%)$ were female, five (50\%) were aged between 51 and 70 years, four (40\%) had incomplete primary education, five (50\%) had colon cancer and four (40\%) were undergoing the FLOX regimen (leucovorin, oxaliplatin and 5-fluorouracil).

Participants answered the evaluation instrument of ET, which comprised questions about the objectives $(\mathrm{CVI}=0.90)$, organization $(C V I=1.00)$, writing style $(C V I=0.93)$, appearance $(C V I=1.00)$ and motivation $(\mathrm{CVI}=0.98)$. CVI was also used in this phase to ensure 
the reliability of the results. The overall CVI was 0.95 , and the validity of content and appearance was evidenced by the target population. A patient suggested the increase in the font size of the ET, due to the patient's low visual acuity. After finishing the content and appearance validation process, the final version presents three topics, and the last one is composed of four subtopics.

Figure 1 shows the final version of the ET - validated for content and appearance by the specialized judges and participants of the pilot test - for fatigue management in cancer patients undergoing antineoplastic chemotherapy in outpatient clinics.

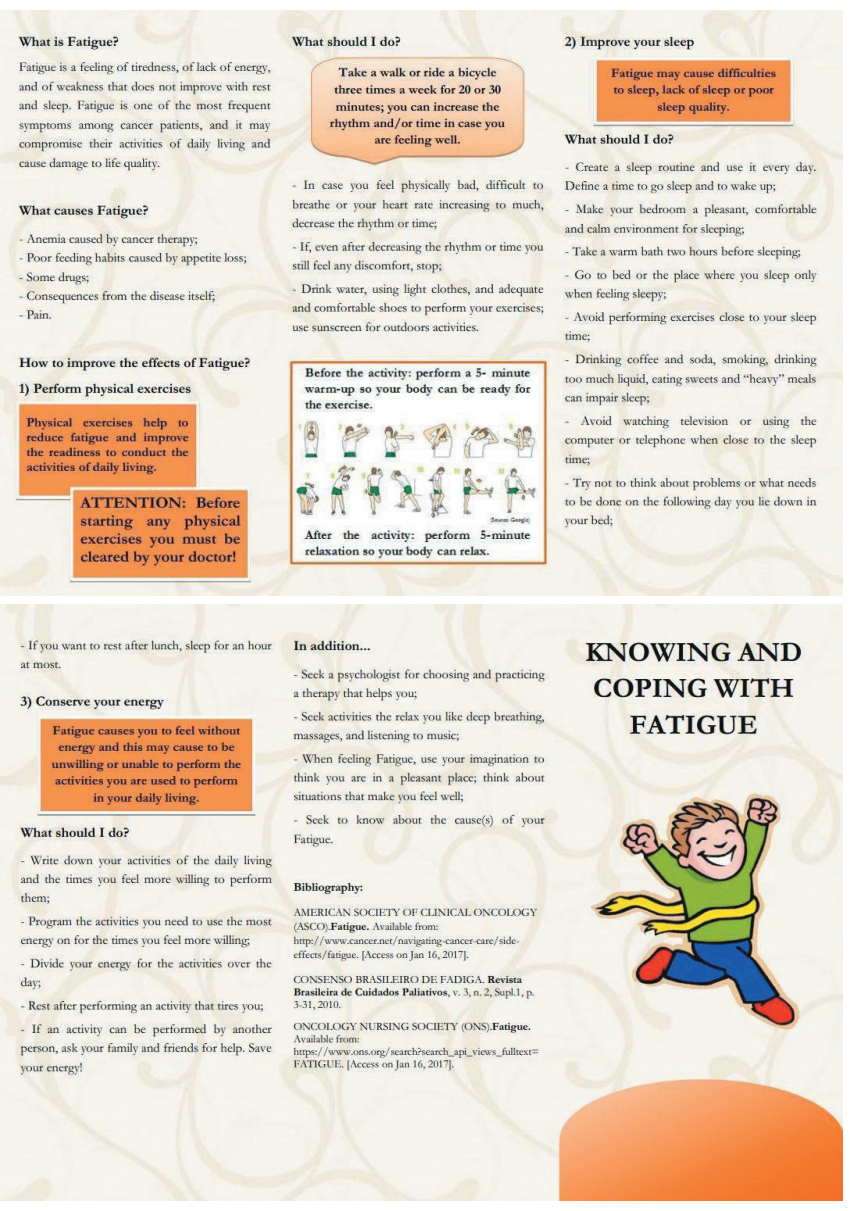

Figure 1 - Final version of the educational technology for fatigue management in cancer patients undergoing antineoplastic chemotherapy, validated by judges and patients, Fortaleza, Ceará, Brazil, 2017

\section{DISCUSSION}

Although fatigue presents high prevalence and its crucial consequences in the life of cancer patients, this condition is not always valued by health professionals ${ }^{(5)}$. The routine evaluation of the presence of fatigue is recommended to these professionals, from the initial diagnosis to the end of treatment ${ }^{(1)}$.

Among the non-pharmacological interventions included in the ET as a strategy for the management of fatigue, we can highlight physical exercises, energy conservation measures, behavioral intervention and sleep hygiene. Performing physical exercises presents a strong level of evidence about its effectiveness in the maintenance of the symptom, with aerobics being the most suggested ${ }^{(6,17-18)}$.
Energy conservation techniques refer to the deliberate and planned management of activities that expend energy, thus preventing its depletion. These strategies include planning, delegation, setting priorities, and scheduling activities that require the use of high energy at peak energy times. These measures aim to reduce energy expenditure in the activities of daily living and are significantly effective in minimizing fatigue ${ }^{(6)}$.

Likewise, behavioral intervention and sleep hygiene presented favorable results in fatigue management, with evidence supporting its use ${ }^{(1,6,19)}$.

A very positive aspect in this study is the long experience in oncology of the judges, and in addition to their knowledge on the oncology area, ET and instrument validation, the fact that the judges are from different geographic regions of Brazil may reflect on different ways of dealing with symptoms.

The judges considered the non-pharmacological interventions proposed for fatigue to be relevant. One of them pointed out that, among the physical exercises suggested as intervention, swimming should be removed, considering that this patient population is often immunosuppressed due to antineoplastic agents have the adverse effect of myelosuppression, which carries the risk of a significant increase in infections. Due to being a natural reservoir for many pathogens, water could make the patient more susceptible to infections. The risk of disease or infection associated with swimming pools is mainly due to the fecal contamination of the water, which may be caused by feces released by swimmers or sources of contaminated water ${ }^{(20)}$, which was confirmed in a study that identified Cryptosporidium and Giardia in swimming pools, leading to the occurrence of outbreaks among swimmers ${ }^{(21)}$.

Still considering physical exercises, a judge stated that the guidelines should include instructions for the patient to ingest water, and wear appropriate clothes and shoes when practicing exercises; the use of sunscreen during outdoors practice was also mentioned. These suggestions were followed. It must be considered that this study was based in the Northeast region of Brazil, with a predominantly tropical climate during the whole year, and that secondary diseases, such as dehydration and skin cancer must be prevented.

In the structure and presentation aspect, the item "Is the typeface adequate?" showed a 1.0 CVI. However, a judge suggested changing the typeface. This was the only unaccepted suggestion, since the theoretical reference adopted ${ }^{(14)}$ points out that a serif typeface, from size 12, is considered easy to read, allowing greater fluidity. This typeface is un-stylized, of Roman origin, with perfect circles and balanced linear forms, making reading easier ${ }^{(22)}$.

The only items that did not reach CVI higher than 0.80 were"font size" $(\mathrm{CVI}=0.71)$ and "Is the folder capable of promoting changes in behavior and attitude?" $(\mathrm{CVI}=0.71)$. Regarding the font size, although the recommendation of the adopted theorists was followed, the judges' suggestion was accepted, since in the pilot study with the patients they also suggested an increase in size. Given the reduced space available, font size was increased from 12 to 13 .

Regarding the item "to promote changes of behavior and attitude", two judges pointed out that the ET alone would not be capable of generating changes of behavior. We must emphasize that the study protocol foresees a quasi-experimental study, which corresponds to the second phase of this work. However, the judges recognized that the ET can contribute to the health 
education process $(\mathrm{CVI}=0.86)$, which is effective for the maintenance of self-care related to fatigue management $(\mathrm{CVI}=1.0)$ and that can be implemented in the daily clinical practice of the nurse who works in an outpatient chemotherapy clinic (CVI = 1.0); thus, being a relevant instrument for the care provided by nursing professionals to these patients $(\mathrm{CVI}=1.0)$. On the other hand, the patients who participated in the pilot study considered the folder to have a motivator effect $(\mathrm{CVI}=0.98)$.

Motivation is the first step for behavior change. A study aimed at the participation of middle-aged people in high-impact physical activity showed that the perception of clear and tangible benefits acts as a motivator for adherence to the practice of physical activities ${ }^{(23)}$. Another study, conducted with patients submitted to stem cell transplantation, reported that being part of a physical activity motivation program reduced the hospitalization period, in addition to arousing a sense of commitment to physical activity, even when the participants were tired ${ }^{(24)}$.

The purpose of written educational material is to reinforce verbal information, act as a guideline for subsequent doubts, and assist in decision making ${ }^{(25)}$. However, these instruments must be developed and validated to be used effectively ${ }^{(26)}$.

\section{Study limitations}

As limitations of this study we can point that the results to be achieved via non-pharmacological interventions for fatigue cannot always be guaranteed, since cancer-related fatigue is multifactorial in most cases and may depend on some pharmacological approaches. On the other hand, the definition of judges is not always easy to achieve. In this study, we chose to use the criteria proposed by Jasper ${ }^{(9)}$, which considers aspects based on clinical experience, but it cannot be guaranteed, in fact, that all items will ensure clinical expertise.

\section{Contributions to the field of nursing}

We believe that the educational technology"Knowing and coping with fatigue" will enable health professionals, especially nursing professionals, to provide care more in line with the needs of their patients, as well as to complement guidelines and clarifications provided to the patient, allowing him/her to better know and cope with fatigue. Furthermore, studies in the context of outpatient care are in line with international efforts to improve nurses' activities in this specialty. In the Brazilian context, the specialty of outpatient oncology still lacks studies that seek to improve the practice of nurses, seeking care based on scientific evidence. We thus believe that the elaboration of an ET may better subsidize the practice of this professional in outpatient environments.

\section{CONCLUSION}

The process of constructing the instrument was based on the search for non-pharmacological interventions based on scientific evidence on how to manage fatigue. The items of the instrument were directed to physical exercises, energy conservation, behavioral interventions and sleep hygiene.

The validation process resulted in the adequacy of content and appearance of the educational technology to guide patients on chemotherapy-related fatigue, with a 0.95 global CVI, indicating an excellent level of agreement among judges. Furthermore, the target population considered the educational technology to be useful considering its objectives, organization, writing style, appearance and motivation, with a 95\% global agreement rate.

Therefore, clinical validation is foreseen in subsequent studies to evaluate the efficiency of the instrument constructed and validated as a facilitator for obtaining data from patients seen at outpatient chemotherapy clinics.

\section{REFERENCES}

1. Bower JE, Bak K, Berger A, Breitbart W, Escalante CP, Ganz PA, et al. Screening, assessment, and management of fatigue in adult survivors of cancer: an American Society of Clinical Oncology clinical practice guideline adaptation. J Clin Oncol. 2014;32(17):1840-50. doi: 10.1200/ JCO.2013.53.4495

2. Herdman TH, Kamitsuru S. Diagnósticos de enfermagem da NANDA: definições e classificação 2015-2017. 10ª ed. Porto Alegre: Artmed; 2015.

3. Mansano-Schlosser TC, Ceolim MF. Fadiga em idosos em tratamento quimioterápico. Rev Bras Enferm. 2014;67(4):623-9. doi: $10.1590 / 0034-7167.2014670419$

4. Deckx $L$, van den Akker $M$, Vergeer $D$, van Abbema $D$, van den Berkmortel $F$, Linsen $L$, et al. The value of fatigue severity to rule out depression in older adult patients with cancer. Oncol Nurs Forum. 2015;42(4):E302-9. doi: 10.1188/15.ONF.E302-E309

5. Berger AN, Mooney K, Banerjee C, Breitbart WS, Carpenter KM, Chang Y, et al. Cancer-related fatigue - version 1.2018. J Natl Compr Canc Netw. 2018:1-62.

6. Caponero R. Consenso brasileiro de fadiga. Rev Bras Cuidados Paliativos. 2010;3(2; Supl 1):1-32.

7. Costa AIS, Reis PED. Complementary techniques to control cancer symptoms. Rev Dor. 2014;15(1):61-4. doi: 10.5935/1806-0013.20140014

8. Doak CC, Doak LG, Root JH. Teaching patients with low literacy skills. 2nd ed. Philadelphia: JB Lippincott; 1996.

9. Jasper MA. Expert: a discussion of the implications of the concept as used in nursing. J Adv Nurs. 1994; 20:769-76. doi: 10.1046/j.1365-2648.1994.20040769.x

10. Pasquali L. Instrumentos psicológicos: manual prático de elaboração. Brasília: LabPAM/IBAPP; 1999. 
11. Canhota C. Qual a importância do estudo piloto. In: Silva EE, organizador. Investigação passo a passo: perguntas e respostas para investigação clínica. Lisboa: APMCG; 2008. p. 69-72.

12. Nicolussi AC, Sawada NO, Cardozo FMC, Andrade V, Paula JM. Health-related quality of life of cancer patients undergoing chemotherapy. Rev Rene. 2014;15(1):132-40. doi: 10.15253/2175-6783.2014000100017

13. Mota DDCF, Pimenta CAM, Caponero R. Fatigue in colorectal cancer patients: prevalence and associated factors. Rev Latino-Am Enfermagem. 2012;20(3):495-503. doi: 10.1590/S0104-11692012000300010

14. Barsevick AM, Dudley W, Beck S, Sweeney C, Whitmer K, Nail L. A randomized clinical trial of energy conservation for patients with cancerrelated fatigue. Cancer. 2004;100(6):1302-10. doi: 10.1002/cncr.20111

15. Oliveira MS, Fernandes AFC, Sawada NO. Manual educativo para o autocuidado da mulher mastectomizada: um estudo de validação. Texto Contexto Enferm. 2008;17(1):115-23. doi: 10.1590/S0104-07072008000100013

16. Souza Neto VL, Silva RAR, Silva CC, Negreiros RV, Rocha CCT, Nóbrega MML. Proposal of nursing care plan in people hospitalized with AIDS. Rev Esc Enferm USP. 2017;51:e03204. doi: 10.1590/s1980-220x2016027203204

17. Al-Majid S, Wilson LD, Rakovski C, Coburn JW. Effects of exercise on biobehavioral outcomes of fatigue during cancer treatment: results of a feasibility study. Biol Res Nurs. 2015;17(1):40-8. doi: 10.1177/1099800414523489

18. Jensen W, Baumamm FT, Stein A, Bloch W, Bokemeyer C, de Wit M, et al. Exercise training in patients with advanced gastrointestinal cancer undergoing palliative chemotherapy: a pilot study. Support Care Cancer. 2014;22(7):1797-806. doi: 10.1007/s00520-014-2139-x

19. Casault L, Savard J, Ivers H, Savard MH. A randomized-controlled trial of an early minimal cognitive-behavioural therapy for insomnia comorbid with cancer. Behav Res Ther. 2015;67:45-54. doi: 10.1016/j.brat.2015.02.003

20. World Health Organization (WHO). Guidelines for safe recreational water environments. Volume 2: swimming pools and similar environments [Internet]. Geneva:WHO; 2006 [cited 2018 Jan 24]. Available from: https://www.who.int/water_sanitation_health/bathing/ srwe2full.pdf

21. Xiao S, Yin P, Zhang Y, Hu S. Occurrence of Cryptosporidium and Giard relationship between protozoa and wate indicators in swimming pools. Korean J Parasitol. 2017;55(2):129-35. doi: 10.3347/kjp.2017.55.2.129

22. Passamai MPB, Sampaio HAC, Sabry MOD, Sá MLB, Cabral LA. Letramento funcional em saúde e nutrição. Fortaleza: EdUECE; 2011.

23. Simmonds BAJ, Hannam KJ, Fox KR, Tobias JH. An exploration of barriers and facilitators to older adults participation in higher impact physical activity and bone health: a qualitative study. Osteoporos Int. 2016;27(3):979-87. doi: 10.1007/s00198-015-3376-7

24. Brassil KJ, Szewczyk N, Fellman B, Neumann J, Burgess J, Urbauer D, et al. Impact of an incentive-based mobility program, "Motivated and Moving," on physiologic and quality of life outcomes in a stem cell transplant population. Cancer Nurs. 2014;37(5):345-54. doi: 10.1097/ NCC.0b013e3182a40db2

25. Moreira MF, Nóbrega MML, Silva MIT. Comunicação escrita: contribuição para elaboração de material educativo em saúde. Rev Bras Enferm. 2003;56(2):184-8. doi: 10.1590/S0034-71672003000200015

26. Benevides JL, Coutinho JFV, Pascoal LC, Joventino ES, Martins MC, Gubert FA, et al. Development and validation of educational technology for venous ulcer care. Rev Esc Enferm USP. 2016;50(2):306-12. doi: 10.1590/S0080-623420160000200018 